\title{
Economic potential of agroindustrial enterprises and their impact on the environment
}

\author{
Igor Aleksandrov ${ }^{1, *}$, Olga Rasskazova ${ }^{2}$, Olga Popazova ${ }^{3}$, Maxim Petrov $^{3}$, and Irina Chekhovskikh ${ }^{4}$ \\ ${ }^{1}$ Petrozavodsk State University, Lenina 33, 185910, Petrozavodsk, Russia \\ ${ }^{2}$ Peter the Great St.Petersburg Polytechnic University, Polytechnicheskaya 29, 195251, \\ St.Petersburg, Russia \\ ${ }^{3}$ Saint-Petersburg State University of Economics, Sadovaya, 21, 191023, St.Petersburg, \\ Russia \\ ${ }^{4}$ Saint-Petersburg State University of Veterinary Medicine, Chernigovskaya, 5, 196084, \\ St.Petersburg, Russia
}

\begin{abstract}
The authors propose an approach to quantifying the potential and intellectual capital of agro-industrial companies. When evaluating the activities of these companies, it is necessary to take into account their impact on the environment. The use of such an universal indicator of the effectiveness of activities as a change in the company's potential will allow taking into account the environmental consequences for the region and territory of the company's economic performance. The paper identifies problems of assessing the potential and intellectual capital of companies. It is proposed to get an assessment of the economic potential of an agroindustrial complex company based on an analytical determination of the probable market price of this company. To do this, the authors suggest using a modified revenue approach to business valuation. Quantitative assessment of economic potential will allow evaluating the company's intellectual capital as a whole, as well as the components of intellectual capital (human capital, structural capital, and client capital). The proposed approach suggests that when evaluating the company's potential, the sum of the net present values of the most preferred projects and the potential residual value of this entity at the end of the project planning period should be taken into account.
\end{abstract}

\section{Introduction}

Russian economy development cannot be based solely on the growth of production due to the exploitation of natural resources. It is necessary to use innovations as a factor in improving the efficiency of the agricultural sector. The importance of the agro-industrial sector is due to the task of improving food security in the context of rapid changes in the modern economy. High-quality strategic management aimed at the long-term development of the economy of regions and territories can not be carried out only at the level of commercial organizations at the expense of the resources of managers and shareholders.

\footnotetext{
* Corresponding author: a7830298@gmail.com
} 
Federal, regional and municipal authorities should also engage in strategic planning in order to determine priorities for the development of their territories. Businesses should be helped to solve the many problems of a worn-out infrastructure. Regional authorities should contribute to the formation of a favorable business climate. The standard of living of the population in rural areas of Russia is lower than in cities. This causes migration of young people, which further worsens the socio-economic situation in rural areas [alex1]. Focusing only on the production of agricultural products in a rapidly changing market environment carries great risks for companies in the agro-industrial complex of Russia. Companies should increase the level of intellectual capital as the main source of competitive advantages. Practice shows [1] that in order to survive, agro-industrial companies have to use all possible resources to expand their activities. This expansion of activity should not be aimed only at expanding the product range. It is necessary to develop the range of services (tourist services, catering, education) and make more intensive use of e-Commerce opportunities.

When making strategic decisions on planned projects, the company's management is faced with the need to assess the effectiveness of selecting an object for investment, which is a difficult task. Rationalization of evaluating the effectiveness of new projects will allow owners and management to increase profitability and reduce risks.

\section{Literature review}

In the modern economy, the value of intangible components of the organization's value can be many times higher than the prices of its tangible assets. Moreover, it is the intangible assets that largely provide companies with competitive advantages. This article develops the previously proposed [1] method for assessing the potential of an organization aimed at determining the impact of Intellectual capital and its components (Human, Structural and Client capital) on this process. The use of this method in analyzing the potential and intellectual capital of agricultural enterprises is designed to take into account the totality of factors that affect the company and help provide new development opportunities for companies in the industry [2]. The agro-industrial complex of Russia has a number of systemic problems that prevent the country from taking a well-deserved share in the total world food production [3]. The significant potential of the industry, due to the scale of unused agricultural land, as well as accumulated developments of domestic Russian science, often remains unused [4].

Despite some positive trends that have been observed in the Russian agricultural sector in recent years[5], it should be noted that a lot of work must be done by the state and business in order for the agro-industrial complex to truly become one of the most important sectors of the country's economy [6]. Improving methods for assessing potential and intellectual capital should help managers of agro-industrial companies in forming an actual strategy for the development of their organizations [7]. As already noted, the most important part of intangible assets is the intellectual capital of the organization [8]. The growth, development and saving of intellectual capital is becoming one of the most important tasks of shareholders and managers in modern economic reality [9]. To assess the effectiveness of this activity appropriate methods are required [10].

Under the intellectual capital of an organization, researchers usually understand " assets that represent mental knowledge, that is, not separable from employees, and knowledge embodied in the results of mental activity (structures, intellectual property, clients, etc.)".

It is customary to distinguish three main components of the company's Intellectual capital. These components are Human and Structural capital, as well as the company's Client capital. Client capital is the value of a relationship with clients. Customer capital is 
also defined as customer loyalty and satisfaction. The client's capital is usually attributed primarily to the company's business reputation and what follows from it. For agribusiness companies, these components may include well-known company names, formal and informal relationships with consumers, partners, and even competitors. This capital includes the presence of regular customers with whom there may be long term or repeated contracts etc. External services that aim to connect consumers and producers, bypassing traditional groups of intermediaries, can help to generate client capital. Such services are eCommerce systems. Despite many quantitative indicators, it is extremely difficult and often impossible to estimate the monetary value of client capital separately from other components of intellectual capital.

The company's structural capital includes a variety of intangible assets necessary for effective business, and is divided into innovation and process components. The innovative part consists mainly of patents, licenses, franchises, etc., as well as ideas, projects, and trademarks. The process capital of an agro-industrial enterprise is the company's infrastructure (technologies, workflows, unique organizational structures, inventory management system, e-Commerce system, security system, customer or supplier solvency assessment system, and many other systems). The main difficulty appears when trying to estimate the total cost of structural capital separately from other components of Intellectual capital. Neither Client capital nor Structural capital can be used effectively if they are not provided with adequate human resources. The last component of Intellectual capital is Human capital, which is understood as the entire set of resources that are contained in the staff. The human capital of an agro-industrial enterprise is not only qualified employees gathered together, but also management.

When analyzing the human capital of agro-industrial enterprises, it is necessary to take into account some specific features peculiar to the agricultural sector, such as:

The worst social working and leisure conditions;

Agricultural work is considered unattractive and unsightly;

Women's labour is used in agricultural production more than in other areas of the national economy.

Human capital cannot belong to an organization. It is important to understand that the employee with the greatest ability does not necessarily have the highest value for the organization. If he does not get the opportunity to sell, he will leave the company along with all the investments.

To quantify human capital, you can analyze the cost of attracting all employees of the company through recruitment agencies and add the costs associated with the adaptation of employees in a new team $[11,12]$.

The main problem of quantitative assessment of Human, Client and Structural capital separately is the difficulty of unambiguously attributing certain intangible assets (business reputation, patents, inventions, etc.) to only one component of Intellectual capital [13]. It is in the aggregate as part of the Intellectual capital that these components create competitive advantages for the organization.

The solution may be to evaluate the entire Intellectual capital with further analytical division of the resulting value of Intellectual capital into Human Structural and Market capital.

\section{Materials and methods}

To assess Intellectual capital, it is proposed to first obtain a quantitative assessment of the company's potential as a total indicator of all the resources and capabilities of the organization [14]. 
The potential of an agro-industrial company forms the market value of this subject, which can be determined directly by the market or analytically. When implementing investment projects, spending financial potential, the company acquires new opportunities that can give both a direct financial return in the short and medium term, and a return in the long term. Identifying changes in the potential of an economic entity can help assess the effectiveness of projects. To analyze changes in potential, it is necessary to define the concept of "potential" and suggest approaches to its assessment. By the potential of an organization, we will understand its ability to generate sustainable cash flows.

The potential of an economic entity acts both as a carrier and as a measure of its capabilities and is the main target factor of strategic management. Increasing the company's potential ensures a steady increase in revenue from its activities and the fulfillment of its mission in the future. The potential includes resources and conditions for expanded resource reproduction, resource conservation, increased reproduction efficiency, and resource conservation.

\section{Research}

In order to develop a profitable approach to business valuation [14], it is proposed to take into account the sum of the net present values of the most preferred projects (PP) and the potential residual value (PRV) of this entity at the end of the project planning period when evaluating the potential of an agro-industrial enterprise:

$$
P^{k}=B^{k}+S^{k}
$$

where $P^{k}$ the potential of company $\mathrm{k} ; B^{k}$ - the sum of the net present values of the most preferred projects for company $\mathrm{k} ; S^{k}$ - the potential residual value company $\mathrm{k}$ at the end of the planning period (net present values of projects do not include cash flows from the sale of assets at the end of the planning period).

The most preferred projects are those with the highest estimated total NPV, selected heuristically by experts. The following groups of projects are proposed to be considered as projects whose net values for a given planning interval determine the potential ( ) of the economic entity $\mathrm{k}$ : group M1 (active)- traditional projects of the economic entity $(\mathrm{m} 11, \ldots, \mathrm{m} 1 \mathrm{w})$, implemented at the time of evaluation; group M2 (planned projects) projects of the economic entity $(\mathrm{m} 21, \ldots, \mathrm{m} 2 \mathrm{q})$, planned for implementation; M3 group (potential projects)- projects $(\mathrm{m} 31, \ldots, \mathrm{m} 3 \mathrm{~g})$ that can be implemented by an economic entity.

$B^{k}$ - the sum of the net present values of the most preferred projects for an economic entity is calculated using the formula:

$$
B^{k}=\sum_{i=1}^{w} N P V\left(m_{1 i}\right)+\sum_{j=1}^{q} N P V\left(m_{2 j}\right)+\sum_{t=1}^{g} N P V\left(m_{3 t}\right)
$$

where $\sum_{i=1}^{w} N P V\left(m_{1 i}\right), \sum_{j=1}^{q} N P V\left(m_{2 j}\right)$ and $\sum_{t=1}^{g} N P V\left(m_{3 t}\right)-$ are the sum of the net present values of $w$ existing, $q$ planned, and g potential projects of the economic entity.

This division of the total cash flow into flows from each individual project can allow a fairly critical approach to their forecasting and assess the risks of each separately.

The company's value at the end of the project planning period should only exceed the net asset value due to the likely high cost of intellectual capital. It is proposed to calculate $\left(S^{k}\right)$ as the product of the discounted market value of net assets $\left.\left(A_{1}^{k}\right)\right)$ at the end of the planning period and the asset utilization coefficient $\left(\alpha^{k}\right)$ :

$$
S^{k}=A_{1}^{k} * \alpha^{k}
$$




$$
\alpha^{k}=\eta * \frac{B^{k}}{A^{k}}
$$

where $\alpha^{k}$ is the asset utilization efficiency coefficient; $S^{k}$ - the sum of the net present values of the analyzed projects for company $\mathrm{k} ; B^{k}$ - the potential residual value of company $\mathrm{k}$ at the end of the planning period; $A^{k}$-the value of net assets at the time of evaluation; $A_{1}^{k}$ the discounted value of net assets at the end of the planning period (excluding cash); $\eta$ correction factor that takes into account the company's business profile after the end of the forecast period $(0 \leq \eta \leq 1)$.

The coefficient $\alpha^{k}$ reflects the return on the initial assets of the business entity, it shows how many times the income $\left(B^{k}\right)$ that the entity can generate using these assets $\left(A^{k}\right)$ for a certain selected planning period exceeds these assets. It is assumed that the assets remaining in the company at the end of the project planning period $\left(A_{1}^{k}\right)$ can be used effectively in the future. This makes it possible to take into account the subject's intellectual capital at the end of the planning period. The correction factor takes into account the possible preservation of the business entity's activity profile after the end of the forecast period. The correction factor is equal to the projected share of the company's sales for previously reviewed projects from the total sales of the company in the next year after the end of the forecast period. In the case where the coefficient $\alpha^{k}$ of the calculation results obtained are less than unity, its value in the calculation of the potential is taken as one.

Based on the above formulas, it becomes possible to solve the problem of analytical assessment of the potential of an agro-industrial enterprise. Since the potential of the company can be seen as a likely market value of the subject, the capacity assessment allows you to evaluate the company's Intellectual capital: Intellectual capital is equal to the difference between the value assess the potential and value of net tangible assets of the company.

\section{Discussion}

After determining the value of the intellectual capital of an agro-industrial enterprise, you can analyze the distribution of the resulting value between the components of intellectual capital (human capital, structural capital, client capital). As a result, you can get a certain probable value for each of the components of intellectual capital.

The choice of potential as an object of management when evaluating, preparing and implementing projects in the agro-industrial complex allows us to take into account all important factors of development, such as: tangible and intangible assets, the efficiency of asset reproduction, projected asset growth, and development prospects. Capacity is the main target factor of strategic management. Only an increase in the company's potential ensures a steady increase in revenue from its activities and the fulfillment of its mission in the future [15]. If there is reliable information and sufficient expert resources for its processing and analysis, as a result of the procedures performed, it becomes possible to solve the problem of determining the company's potential and solving the problem of determining the company's potential increment. An assessment of potential growth as a result of a planned major investment project or an upcoming $\mathrm{m} \&$ a transaction can be used to analyze the effectiveness of this transaction. The method can be used to evaluate the effectiveness of possible transactions related to the sale of a part of the company. To do this, you need to evaluate the potential before and after the proposed transaction and compare the results. 


\section{Conclusion}

The paper identifies problems of assessing the potential and intellectual capital of agroindustrial companies. It is proposed to get an assessment of the economic potential of a company based on an analytical determination of the value of this company. To do this, the authors suggest using a modified revenue approach to business valuation. The proposed approach to capacity assessment allows us to assess the value of intellectual capital of companies. It is possible to obtain a certain probable value for each of the components of intellectual capital. The use of such index performance as a change in the intellectual capital of the enterprise, will allow to consider the environmental consequences for the region and territory business enterprises.

\section{References}

1. M. Fedorova, I. Aleksandrov, Digital economy and green economy: rural unemployment and territorial self-development in Russia, E3S Web of Conferences 110, 02019 (2019) https://doi.org/10.1051/e3sconf/201911002019

2. N.A. Mironova, K.K. Kharlamova, O.A. Plastinina, Enterprises of Small Forms of Management Condition and Developing in the Vologda Region, Scientific Journal "Dairy Bulletin" 16 (4), 97-106, 2014

3. O. Rasskazova, O. Kalinina, E. Zotova, Modern transformation of the production structure and its impact on the content of labor and the requirements for the skills and abilities of workers, MATEC Web of Conferences 170, 01041 (2018) DOI: https://doi.org/10.1051/matecconf/201817001041

4. V. Erokhin, W. Heijman, A. Ivolga, Sustainable Rural Development in Russia Through Diversification: The Case of the Stavropol Region, Visegrad J. Bioec. \& Sust. Dev., 1, 3, 20-25 (2014) DOI: 10.2478/vjbsd-2014-004

5. E.V. Zhirnel, L.M. Kulakova, Sustainable development and modernization of the economy of rural areas in Russia, Transactions of KarRC RAS 3, 35-34 (2015) DOI: 10.17076/reg82i

6. M. Yu. Fedorova, The scientific journal of the State Commission for Academic Degrees and Titles «Regional problems of transforming the economy» 3 36-43(2017) DOI:10.26726/2305-4484-2017-3-36-43

7. C. Ray, Culture Economies: a perspective on local rural development in Europe, Centre for Rural Economy, Dept. of Agricultural Economies and Food Marketing, 2001

8. H. Samah, Azril Mohamed Shaffril, J. Lawrence D'Silva, M. Abu Hassan, Information communication technology, village development and security committee and village vision movement: A recipe for rural success in Malaysia, Asian Social Science 4, 13644 (2010)

9. N. Kolesnikov, N. Kolesnikova, Spatial economic effects of the use of local resources: case of cement-bonded wood fiber blocks, MATEC Web of Conferencesб 193, 03041 (2018) DOI: 10.1051/matecconf/201819303041

10. V. Plotnikov, O. Pirogova, Intellectual capital management within the framework of the VBM concept, E3S Web of Conferences 157, 04007 (2019) DOI https://doi.org/10.1051/e3sconf/202015704007 
11. O. Rostova, S. Shirokova, N. Sokolitsyna and A. Shmeleva, Management of investment process in alternative energy projects, E3S Web of Conferences 110, 02032 (2018) DOI:https://doi.org/10.1051/e3sconf/201911002032

12. M. Zharova, S. Shirokova, O. Rostova, E3S Web Conf. 110, 02033 (2019) DOI: https://doi.org/10.1051/e3sconf/201911002033

13. C. Cunha, E. Kastenholz, M. J. Carneiro, Entrepreneurs in rural tourism: Do lifestyle motivations contribute to management practices that enhance sustainable entrepreneurial ecosystems?, Journal of Hospitality and Tourism Management 44, 215-26 (2020)

14. I. Aleksandrov, M.Fedorova, 2017 New Approaches In The Strategic Development Of Rural Tourism As A Tool Of Regional Economics Development Sc. J. of KubSAU 10 Doi: 10.21515/1990-4665-134-063

15. A Bril., O Kalinina,. A Kankovskaya,. V Vilken, Operational risk management in financing environmental activities and personnel management projects, E3S Web of Conferences 110, 02018 (2019) DOI: 10.1051/e3sconf/201911002018 